Nadwa : Jurnal Pendidikan Islam

Vol. 12, Nomor 2 Tahun 2018

Accredited by Ristekdikti based on Decree No. 51/E/KPT/2017

\title{
The Growth of Learning Enthusiasm at the Emeyodere Moslem Minority Education Institution in West Papua
}

\author{
Ismail Suardi Wekke \\ Sekolah Tinggi Agama Islam Negeri (STAIN) Sorong \\ E-mail: iswekke@gmail.com
}

\section{Fitri Ruaidah}

Sekolah Tinggi Agama Islam Negeri (STAIN) Sorong

E-mail: fruaidah@gmail.com

\section{Moh. Wardi}

STAI Nazhatut Thullab Sampang

E-mail: mohwardi84@gmail.com

\begin{abstract}
The purpose of this study was to find out what factors could trigger the enthusiasm of the Emeyodere foundation students. This study uses a qualitative descriptive research method. The results showed that first, the leadership factor of the foundation, the foundation aim was to elevating the Kokoda tribe from educational backwardness. Second, motivation factor. Third, aid factor, the foundation provides assistance or donations such as books, stationery for every semester, school uniforms for disadvantaged students, and supplementary meals every two weeks.
\end{abstract}

Keyword :; enthusiasm; moslem minority, west papua; education;

\begin{abstract}
Abstrak
Tujuan penelitian ini adalah untuk mengetahui faktor-faktor apa saja yang dapat memicu semangat peserta didik yayasan Emeyodere. Penelitian ini menggunakan metode penelitian deskriptif kualitatif. Hasil penelitian menunjukkan bahwa pertama, Faktor kepemimpinan yayasan, yayasan ini didirikan dengan tujuan untuk mengangkat derajat suku Kokoda dari keterbelakangan pendidikan. Kedua, faktor motivasi, ketiga, faktor bantuan, pihak yayasan memberikan bantuan atau sumbangan berupa buku-buku dan alat tulis pada setiap semester, seragam sekolah bagi peserta didik yang kurang mampu, dan makanan tambahan setiap dua minggu sekali.
\end{abstract}

Kata Kunci : minoritas muslim; Papua; Semangat Belajar

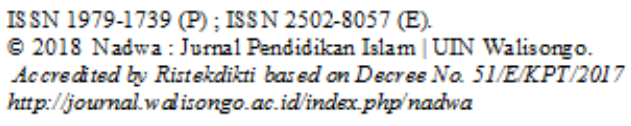




\section{Introduction}

Emeyodere Foundation is an educational institution founded by the prominent muslim figure from Kokoda tribe, Mr. Ismail Agia. Kokoda tribe is one of the tribes originating from Papua (indigenous people). This community spreads in five territories in the city of Sorong and occupies areas outside the city. Kokoda community comes from several tribes that live together in the same areas. The tribes are; Migori, Kasweri, Siwatori, Tarof, Nebes, Udagaga, Benawa, and Tambani.1 Although they come from various tribes, they are generally known as the Kokoda tribe and they practise two different religions, namely Islam and Christianity.

The name of the foundation, "Emeyodere", was taken from a word that is derived from the origin language of the Kokoda itself which means invitation to do something. "Eme" means "Come" and "Yodere" means "Immediately". In conclusion, the meaning of the word "Emeyodere" is an invitation to immediately move to a better condition, especially in the field of education. There are several factors that become the basic things on how this foundation established. The first factor is the lack of awareness of the importance of education among some communities in Kokoda. Then, the second factor is the lack of enthusiasm for learning among the young generation in Kokoda. Because of the major factors mentioned, the society think that it is fine if their children do not have willingness to go to school and learn. As a result, this situation give profound impact on their social and everyday life.

Emeyodere Foundation is located on Jl. Victori $\mathrm{Km}$. 10, precisely on the coast of Victori. The foundation has Madrasah Ibtidaiyah (MI) and Madrasah Tsanawiyah (MTs) as the islamic formal educational institutions

1Muhammad Rais, "Islam dan Kearifan Lokal; Dialektika Faham dan Praktik Keagamaan Komunitas Kokoda-Papua dalam Budaya Lokal" Makalah (Sorong, STAIN Sorong, 2010), p.2. 
alternative to elementary school and junior high school. In addition, the foundation also has Islamic boarding schools that are provided for their students. Previously, this foundation was named Salafiyah Islamic Boarding School (Pondok Pesantren Salafiyah) which was established in 2006. Salafiyah Islamic Boarding School had 9 year compulsory education program, namely 'ula and wustho as non formal levels. Then, in early 2009 Salafiyah Islamic Boarding School was established in several locations in the city of Sorong: in Ruvei, in Jalan Baru $\mathrm{Km} .8$ and in Jalan Baru Km. 10. Some islamic boarding schools in those places already have students although the number of the students is not significant. Consequently, evaluation meetings were held because the islamic boarding school need to take significant developments to improve the situation.

From 2009 up to now (2012), the islamic boarding school had developed into a formal education with the named of "Emeyodere Foundation". So, the school which the name under Salafiyah Islamic Boarding School only lasted for 3 years, that was during the period from 2006 from 2009. Emeyodere Foundation provides Islamic boarding Schools, A, B and C package programs, and islamic educational institutions (MI, and MTs). After the islamic boarding school changed to be Emeyodere foundation, the number of the students increased and they do not only come from kokoda community, but the students also come from Ambonese, Makassarese and from other communities.

This study focused on the efforts that could be take to increase the enthusiasm of the students to actively participate in learning activities. Where in fact only a small number of the Emeyodere Foundation's students who have immense enthusiasm in participating in learning activities. However, to make sure that the learning system works well there must be enthusiasm from the students and educators so that the teaching and learning process 
can run. Students' enthusiasm can be cultivated by giving them motivation that can attract their attention so that they the have willingness and spirit to learn subsequently.

The research on the increasing enthusiasm of Emeyodere Foundation's students to actively participate in learning activity is interesting to do due to the fact that only a small number of the students who have positive attitude toward the spirit. Based on their social background, the students are famous for the stubborn nature and have the priority to have activity in the market higher than priority to study at school. The culture is still attached among the young generation from the community they come from. Therefore, Emeyodere foundation was established with the aim to awaken the community (Kokoda) to realize that education is the main need for their future generation. Various efforts have been taken to increase the students' motivation but it is still difficult to reach the goal because the negative culture influenced by the community is still very embedded and has strong impact on the growth and development of the young generation of the community.

Based on the facts described above, there is one interesting main problem to be examined in this study: how to increase the enthusiasm of the students to actively participate in learning activities? To answer this problem, this study will focus on the discussion on three main issues. First, how the condition of the Emeyodere Foundation is. Second, the map of the learning system implemented in Emeyodere Foundation. Lastly, the factors to increase the willingness and spirit of the Emeyodere foundation's students to study.

\section{The Part Picture of the Emeyodere Foundation}

This research was conducted on some of Kokoda's children who are studying at the Emeyodere Foundation, the students are from MI Emeyodere and MTs Emeyodere. This research was carried out for three months, starting 
from October to December 2012. The data in this research was obtained from several educators (teachers), especially from the principal of MTs (Muhammad Beyete) and the principal of MI who is concurrently a chairman Emeyodere Foundation (Ismail Agia).

The word condition meant in this research is the one that explains about a situation or learning environment of students, where the learning environment is very personal for every student in carrying out the teaching and learning process. If a student learns in a healthy environment, they will definitely have healthy personality and their personality health will contribute well to the community as a whole.2 Just like the Emeyodere Foundation which is located on the beach of Victori that is very far from the crowd of the city of Sorong, so that every student must have strong willingness and spirit in contributing and participating in the learning activities. In addition, the school is still in the development stage, yet has increased in recent years, from 2009 to 2012. In 2009, there were only two classrooms for teaching and learning, but over time, this school learned and successfully increased the number of classrooms and boarding houses for the students of Emeyodere Foundation.

The school building, the classrooms, as the learning space is the first absolute requirement that must be fulfilled to establish a proper educational institution (foundation). After that, it is followed by other facilities that are able to support the teaching and learning process. The facilities includes the complementary tools besides the media that can help to support the learning process. For example, tables, chairs, textbooks or familiarly known as "printed books", blackboards, and so on. Emeyodere Foundation also has facilities that have been fulfilled to

2Sudarwan Danim, Pengantar Kependidikan Landasan, Teori, dan 234 Metafora Pendidikan, (Bandung, Alfabeta, 2010), p. 166. 
help the students to study during the teaching and learning processes. The facilities meant are the blackboards, tables, chairs, notebooks and subject books (LKS). It is very reasonable if there is a lack of facilities in the foundation, because Emeyodere Foundation is one of several educational institutions in the city of Sorong which is still in the developing phase of school development, so that the foundation still needs attention from the government and the Education Authorities of Sorong city.

One of the tasks that must be carried out by the teachers (the educators) at the school is to provide services to students so that they can become students as the school wants them to be.3 The teachers are the source of knowledge, instructors and mentors for students. Every school has different numbers of students, as well as its quality. But, basically, a process of education is essentially just the same. Every teacher has the aim to humanize humans. The Emeyodere Foundation has very poor number of teachers, where there is still a shortage of teachers based ont the subjects taught at the school, such as mathematics teachers, science teachers, and there are still other subjects that need more teachers. In the Foundation, there are 9 students from MI school (Madrasah Ibtidaiyah) and 7 students from MTs (Madrasah Tsanawiyah). From the number of the teachers teaching in that foundation, according to the statement of the head of the Foundation, there is no teacher who has permanent status, all of whom are still temporary employees (honorer). Herein, the foundation needs serious attention from the government to see the condition of every Islamic foundation in West Papua. To advance an Islamic education, it is necessary to improve the quality of its teaching staff in order to manage educational

3Oemar Hamalik, Proses Belajar Mengajar Cet. XI, (Jakarta, Bumi Aksara, 2010), p. 33. 
institutions and to be able to improve the quality of the students as the next generation.

The learners are the main goal in the teaching and learning processes. Without the students, the teaching and learning processes will not work as desired. This is because the students are the objects of knowledge to transfer and individuals who still need guidance and teaching in order to grow into adults who have good characters and knowledge. Effective teachers need to understand their students' growth and development comprehensively. This understanding will make it easier for teachers to assess their students' needs and plan to achieve goals, materials, and teaching and learning procedures appropriately.4 The growth and development of the students depend on the environment set at the school, the environment in the community, and the most important is the environment in the family. Those three environments are interrelated and influence each other. While the main purpose of the establishment of the Emeyodere Foundation was to renew the condition of the school, the condition of the community and the conditions of each family from the Kokoda tribe.

The researchers set that goals because Kokoda tribe is known as a community prioritizing the development of the economy than the aspect of education for the young generation. However, the economy condition could be increased by increasing the education level (intellectual), especially increasing the education of the local youth as the native Kokoda tribe of Papua. Unfortunately, the level of education awareness in every family in the community is still far from high. Therefore, the foundation was established to change the views of the families and even the society in general about the importance of education. And finally, in 2012, the Emeyodere Foundation received

4Oemar Hamalik, Psikologi Belajar Mengajar Cet. VII, (Bandung, Sinar Baru Algensindo, 2010), p. 93. 
161 new students. This significant number of students is not easily achieved by every school, especially with the average students which come from the origin Kokoda tribe which are famous for their "Stubbornness". So, the teachers face difficulties to trigger the spirit of learning the students during the teaching and learning processes.

However, economics and education are always related between one and the other. Somehow, people will prefer to go to work than go to school. They are the type of people whose the economics level below average, which means they are far from economic welfare. In developing community, generally they have many children who live in families who are below the poverty level. The poverty level is could trigger the occurence of the symptoms of frustration, anxiety, shame, and often acts of aggression. The symptoms of mental disorders like this may be caused by the psychological influence by their parents or the influence from the attitude of the surrounding community who underestimate and demean them or because of the lack of nutrition and health problems that are related to their limited purchasing power. 5 This is what happens to the indigenous Papuans in general, so that it will lead some possibilities to happen.

The possibilities that will occur are, first, the children do not have interest in learning or interest in school or there is no time to go to school because they are busy helping their parents work. This is the first possibility that will occur, because wherever and whenever the children enjoy the pleasure of having their own money without having any other motivation that encourages them to go to school, they will neglect their obligation to study. They will be more inclined to go to work to earn money. Then, the second possibility is that there is a reverse reaction, that is because of the poverty, the high motivation grows to learn to better their future better,

sIbid, p. 23. 
unlike what their parents believe to happen.6 This possibility can occur if the motivation they get is high so that they can overcome the feeling of laziness or lack of enthusiasm to go to school.

In the book written by Oemar Hamalik (2009) entitled Psychology of Education, it says that there are several efforts that can be done to help children (students) from poor families. Namely: (1). To raise awareness of their parents so that they will send their children to school, of course by providing facilities, both by the school and the government, (2). Provide special cost assistance provided by the government as a special fund for poor children, (3). Implementing increase care systems performed by economically capable parents, also by raising funds from the community, for example collecting funds through Koperasi or others, (4). Freeing the obligation to pay donations or funds in any form for them and seeking for incentives that are of interest to them, such as employment, continuing school, and others that stimulate them to learn. The four things above have been attempted by Emeyodere Foundation, but still considered quite difficult to be fully implemented because of the lack of support from the community and the attention from the local government.

\section{Learning System Practice at Emeyodere Insitution}

According to the book Pengantar Sosiologi Pendidikan, system is an ordered relationships between elements or parts to form totality.7 In addition, it can also be said that the system is a group or elements that are interconnected independently (interdependence) and constant.8 The groups or elements that are interconnected are teachers, principals, curriculum, learning methods,

6Ibid.

7Damsar, Pengantar Sosiologi Pendidikan, Cet. I, (Jakarta, Kencana, 2011), p. 94.

sIbid, p. 95. 
media, and other things that are able to support learning activities. Every school has different systems, especially the one implemented in the teaching and learning processes. This is because the background or goals (vision and mission) of each school are not the same.

In addition to the different teaching and learning systems, every educational institution has inequality in its teaching and learning process. This is due to the different conditions of each school. But, in general, educational institutions use the same time in carrying out their learning activities: from morning to afternoon; from Monday to Saturday. This is what also is done by Emeyodere Foundation which consists of formal schools and Islamic boarding schools. The foundation conducts the learning activities that start in the morning and in the evening. The formal schools are held in the morning, while the Madrasah Diniyah are held in the afternoon. The Madrasah Diniyah is dedicated to students who become santri at Emeyodere Foundation.

There is little difference that, according to the researchers, is precisely the uniqueness of the Emeyodere Educational Institution. The first is that the pesantren (boarding school) in the Foundation are the schools that are still in the developing and growing stages, so that the systems applied are still in a fray, which means that the pesantren initially only wanted to assist students because of their economic and intellectual backgrounds only. Hence, the lessons only focus on deepening what has been taught in the formal school and the subjects of religious matters. So, the schools are not using traditional systems such as Waton, sorogan, kitab kuning and so on, and also do not use modern systems that we can see in modern pesantren that are developing today, such as by applying two languages (Arabic and English). So that it can be said that the schools are still in the stage of identity formation.

In addition, the second difference that stands out from other schools is that the students consider Friday and 
Saturday to be free days, so most of the students do not attend the school on those days. It is only a few of them attending the Friday and Saturday classes. It is considered to be very reasonable by all teachers and the surrounding community, because beside the school is a school that is still in the development stage, it is not fully aware of the importance of education embedded in the personalities of their students.

If an educator, who is always involved in the teaching and learning processes, wants to achieve the teaching goals effectively and efficiently, he or she will realize that only mastering the materials is not enough. The educator or teacher must master various techniques or methods of preparing materials and can implement the right methods in the teaching and learning processes in accordance with the material taught and the ability of students who receive the subject matter.9 The selection of the right techniques and methods to be used in classes would indeed require the teacher's own expertise. The teacher must be good at choosing and using techniques and methods that they will use in the teaching and learning processes. From the statement above, it can be said that the method is a way or procedure that must be passed to present teaching materials in order to achieve the teaching objectives.10 In addition to achieving the learning goals, the method should also can make the students always active in contributing and participating in the learning process. In some cases, there is a possibility that students lost their enthusiasm to learn because they do not like the teachers or because they find it difficult to understand the subject taught by their teachers. Hence, the use of correct methods in each teaching and learning process is very important.

9Ramayulis, Metodologi Pengajaran Agama Islam Cet. III, (Jakarta, Kalam Mulia, 2001), p. 107.

10Ibid, p. 108. 
There are many methods that can be used in the teaching and learning process, including: (1) lecture method, (2) discussion method, (3) question and answer method, (4) demonstration method, (5) method of field trip, (6) assignment method, (7) Problem solving method, (8) Simulation method, (9) Experimental method, (10) Discovery method, (11) Unit method, (12) Socio drama method, (13) Group work method, (14) Community Study method, (15) Programming teaching method, (16) Module method, and others.11 All the methods mentioned may be used in the teaching and learning processes in either Islamic religious education or other sciences classes, as long as they do not deviate from the underlying principles. In addition, the researchers are also unable to mention which method is the best or the most effective because if the understanding level ofstudents is different, the method used should be different.

In carrying out a teaching and learning processes, a media is also needed to support and help students in understanding the lessons provided by the teacher. One characteristic of learning media is that the media should contains and carries messages or information to recipients, the students.12 The messages and information carried by the media can be simple messages or can be the very complex one. However, the most important thing is that the media is prepared to meet the learning needs and abilities of the students and the students can actively participate in the teaching and learning processes.13 All in all, every school must be able to prepare an interactive learning environment that is able to answer and meet the learning needs of the students in their education environment by providing media to establish effective learning relationship.

11Ibid, p. 109.

12Azhar Arsyad, Media Pembelajaran, Ed I, (Jakarta, Raja Grafindo Persada, 2008), p. 81.

13Ibid. 
The media that is meant is, first, the one that can be in the form of human-based media, namely teachers, instructors, tutors, role playing, group activities, and others. Second, print-based media such as books, workbook guides or exercises and task sheets. Third, visual-based media such as books, Charts, graphics, maps, figures or images, transparency, film frames or slides). Fourth, audio-visual based media, such as videos, films, slides with tape, and television. Fifth, computer-based media, for example, teaching with the help of computers and interactive videos. And Sixth, library media that is used as a learning resource.14 From the various types of media mentioned above it seems that the puropose is to help students understand complex lessons, so that it is necessary for each school to provide and improve learning media used by each school or institution.

The discussion about learning media is very important. Emeyodere Foundation needs to provide media that should be mind by the managers of foundation and the local government. The students are in the condition and in state of desperation in needing of help and support to grow their sense of learning. For example, in Emeyodere Islamic Junior High School and Madrasah Tsanawiyah, there are only media in the form of teachers, blackboards and subject books. These three media sometimes make the students feel bored, so it is necessary to add more media such as television, VCDs, and other lesson disk tapes that can be used to educate the students and help them to understand the lessons taught by the teachers. Every student has different way to strengthen their memory in studying, such us through visual, audio, and practicing.

14Ibid, p. 82. 


\section{Factors That Can Trigger Emeyodere Foundation Students Enthusiasm in Learning}

Even if you put your energy, enthusiasm and implementing student-based teaching approach, sometimes your students only sit in their chairs and yawn before you. Even though you have spent a lot of time creating interesting lesson plans, your students might not interested. Even though you are a well-educated person and loves your expertise, your students might not show any attention. They take a deep breath and constantly glanced at the wall clock. Their minds fly and you and your lessons are not a part ot it. They widened their eyes and shook their heads, 15 From that description, LouAnne Johnson proves that all of that are the characteristics of students who are lazy in following the teaching and learning processes in a classroom. Therefore, a teacher needs to provide motivation in order to bring up enthusiasm in the students.

Motivation is a tool used to increase enthusiasm among students, it has long been understood that motivation is a driver for every individual to behave.16 The term motivation shows all the symptoms contained in the stimulation of actions towards a specific goal where previously there was no movement towards the goal. As a problem in classroom, motivation is the process of generating, maintaining and controlling interests.17 Thus, in the process of teaching and learning, students in a classroom, or anywhere, always require the existence of motivation in them.

In the context of education, at Emeyodere Foundation, the students require more motivation. Where the majority of the students com from Kokoda tribe that

${ }_{15}$ LouAnne Jhonson, Pengajaran yang Kreatif dan Menarik, Cet. II, (t.t, Indeks, 2008), p. 198.

16Esa Nur Wahyuni, Motivasi dalam Pembelajaran, Cet. I, (Malang, UIN Malang Press, 2009), p. 3.

17Oemar Hamalik, Psikologi Belajar Mengajar....., p. 173. 
lack of awareness of the importance of education. For example, in one week, every Friday and Saturday most of the students do not attend the class because they consider those two days are free days. So, on fridays and saturdays the students do not come to the school.

The existence of motivation in learning is very important to influence the aspects of learning. Students who have been motivated will be different from students who are still less motivated. Students who are motivated will show their enthusiasm, trying to achieve maximum value, and doing every task given by the teacher.18 This has also happened to some of the students from Emeyodere Foundation, although they are famous of lacking interest in learning, but when the researchers conducted this study, the researchers found out that some students were motivated in learning. The behavior that showed that they are motivated could be seen when they were choosing subject books in which there are interesting images that are able to help them to understand the reading material. The interesting pictures arouse their enthusiasm to learn at school.

Motivation and learning are factors that greatly affect the students. By learning, students could achieve a lot of information that influences their physical growth, mental development, and knowledge in their mind. While motivation is a driving force or encouragement so that the students have a sense of learning. Motivation can be in the form of basic or internal and intensive external impulses or gifts. 19 The point is that motivation can be created by the teacher in the form of examples of action, advice, compliment, and gift. So, with the encouragement from the outside, there will be encouragement for the students to do something they have never done before.

18Esa Nur Wahyuni, Motivasi dalam Pembelajaran......, p. 3. 19Oemar Hamalik, Psikologi Belajar Mengajar....., p. 173. 
Motivation is very important in teaching and learning processes, because motivation has several functions, including: (1) Encouraging people to act, as a driver or motor that release energy. Motivation in this case is the driving force to do every activity. (2) Determining the direction of actions to achieve goals. Thus, motivation can provide direction and activities that must be done in accordance with the formulation of the objectives. (3) Selecting actions, by determining what actions must be taken that are harmonious in order to achieve goals by setting aside actions that are not useful for that purpose. 20 Besides, there are also other functions of motivation that can function as a driver of business and achievement, someone will do an effort if there is motivation in him. Furthermore, the existence of positive motivation will produce positive result, too. This means, with good effort and strong motivation, someone will get good and satisfying result. In conclusion, the level of motivation a student has will determine the learning outcomes or achievement they will get.

In an effort to increase motivation and enthusiasm of learners, various efforts have been made by Emeyodere Foundation. For instance, notebooks, uniforms and supplementary food are distributed in every semester. In addition, each teacher sometimes gives motivation to his or her students, the motivation is in the form of giving cakes or other food purchased by the teacher so that students have willingness to follow the subjects taught in the class. However, it is still considered to be difficult enough to increase students' interest in learning because the same thing did not happen as how it was when the study was conducted. In fact, the motivation in learning just came up after those various attempts were done

20Sardiman, Interaksi dan Motivasi Belajar Mengajar, Ed. I, (Jakarta, Rajawali Press, 2008), p. 85. 
without hesitate which so much different with how it was since 2009.

In Oemar Hamalik's book (2010) there are several ways that can be used by teachers to drive student learning motivation. First, by giving scores. Students generally want to know the results of their work, the score given by the teacher. If a student gets good grades, he or she will be motivated to get better grades and vice versa. Second, by giving praise to students or the things that have been done successfully. It is likely that they will be able to encourage them to learn more. Third, by giving gifts, this method can also be done by teachers but only within certain limits, such as giving gift for the best achieved student, student who wins a competition, and others. Fourth, by doing group work. In group work, students should do collaboration in learning, each group member will participate has a feeling to achieve the best for the sake of the group he or she belongs to so that it makes them better in learning. Fifth, by holding a competition. Either group work or competition has social motive to students. However, it should be kept in mind that individual competition will lead to negative things. Sixth, the purpose and level of aspiration from the family will encourage the activities of students. Seventh, doing sarcasm by inviting students who have less learning outcomes. Within certain limit, sarcasm can encourage motivation in learning, but on the other hand it can lead to the opposite thing because a student could feel he or she is insulted and conflict could come up between the teacher and student. Eight, by means of continuous assessment that will encourage students to learn, because every student has a tendency to get good results. Nine, field trips and excursions, this method can generate learning motivation because the students will get direct and meaningful experience. Ten, watching educational film. Each student will be happy to watch a movie because the picture and content from the movie could attract students' attention in learning. And, eleventh, 
learning through radio. Listening to the radio will be more interesting than listening to the teacher's lecture. Radio is an important tool to encourage student learning motivation. Even so, the position of the radio may not be able to replace the position of a teacher to the students. There are many other ways that can motivate students to study harder, but it would be better if the motivation grows from within. For example, the need for motivation, awareness of goals and also the teacher's personality that will influence and stimulate students' motivation.

\section{Challenges and Recent Condition}

The establishment of Emeyodere Foundation is one of the efforts to increase interest in learning and awareness of the importance of education for Kokoda community. We do not want to see the people of Kokoda live in certain places and they only have some child from their young generation that successfully continue their education to university level. However, it is very difficult to change the bad habits they have. This is in accordance with the research done by Ismail Suardi that the existence of pesantren or yayasan cannot be separated from environmental awareness and the development of pesantren starts from observing environmental conditions.21 Hence, it can be said that the existence of educational institutions, foundations or even Islamic boarding schools in certain regions or places, can be guidance for the community to better their condition because the services offered by these educational institutions are from the community and for the community as well.

21Ismail Suardi Wekke, "Pendidikan Islam dan Pemberdayaan Masyarakat (Tinjauan Pendidikan Vokasional Pesantren Raudhatul Khuffadz, Sorong)" Hermeneia, Jurnal Kajian Islam Interdisipliner (Yogyakarta, Program Pasca Sarjana UIN Sunan Kalijaga, 2002), p. 47. 
The efforts to increase students' motivation are still considered very difficult because the negative tradition or thoughts of indigenous Papuans are strong and embedded in society. But, teachers and instructors can give and instill four Pillars of Education which, according to the researchers, is in accordance with the way of thinking of the Kokoda community, UNESCO (United Nations Educational, Scientific and Cultural Organization) as a part of the United Nations Organization for Education, Science and Culture has outlined four pillars of education: first, learning to know as the foundation of science; second, learning to work, application; third, learning to be to explore potentials; fourth, learning to live together, to live in partnership and at the same time be competent, live side by side and be friendly among nations.22 But if you want to apply it specifically for indigenous Papuans, then we can use "Learning to know, learning to work, learning to be and Learning to live together". As a result, the thought that we can know, can work, can be what we want and can live together in any society without any sense of sensation or exclusion through education.

The four pillars of education mentioned above are: First, learning to know the meaning of learning that takes place in schools that is generally intended to encourage students to gain knowledge in a structured manner. In addition, to master learning tools. Positioning learning as a tool means that people must learn to understand the world around them, at least as much as they need to live a dignified life, develop work skills, and communicate with others.23 So that learning is an intermediary of humans in carrying out life to not get lost and misled by the provision of knowledge they have.

Second, learning to work. In an increasingly advanced economic system, there is a shift in work from

22Sudarwan Danim, Pengantar Kependidikan......, p. 131. 23Ibid, p. 131. 
the physical to service industry.24 This means that we can see the economic development on the island of Papua, especially in West Papua, that the majority of people who have large businesses are migrants, while the majority of indigenous Papuans only seek and sell coral and mangrove or manrove, 25 This proves that the lack of education among them is one of the factors that causes them to only work improperly or according to them is the work done by their ancestors. However, indigenous Papuans (Putra Papua) have been guaranteed to get decent jobs, especially in the field of government, only if they are able to achieve high education.

Third, learning to be. Humans must grow into themselves, human development begins at birth to death. It is a dialectical process based on knowledge and personal relationships with others. This requires successful personal experience, as a means of personality training. Education must be a very individual process and, at the same time, experience social interaction.26 It has been proven that every Papuan community who has broad insight, sufficient experience and high education will gain an honorable position in a society especially if they have good personalities and characters and become truly respected. But, unfortunately, those who have such characteristics are only a few from all levels of society who are aware of the importance of their life to use it as well as possible.

Fourth, learning to live together. The task of education is good in the context of learning for students and about human diversity as well as to instill their selfawareness about the equality and interdependence of all of their essence, how they are able to live together with others in a friendly and pleasant way. From early childhood, the process and substance of learning is to seize every opportunity to pursue various branches of

24Ibid, p. 135.

25Muhammad Rais, Islam dan Kearifan Lokal...., p.2.

26Sudarwan Danim, Pengantar Kependidikan......, p.137. 
knowledge that lead to this goal. There are recommendations, when entering elementary education, children must be equipped with human geography, foreign languages and literature.27 Herein lies the importance of education. So, in living as a social being, besides prioritizing goodness and mutual understanding, we must also prioritize science that we often hear that 'science is a lamp of life'. Without having knowledge, we are among those who are blind. For example, when someone has abundant wealth but he has no knowledge, he will be confused about how to use his property properly. This means that science is the main modal to live a life.

\section{Conclusion}

Emeyodere Foundation is a foundation founded by a prominent muslim figure from Kokoda tribe, Mr. Ismail Agia. The foundation was established with the aim to free Kokoda tribe from educational backwardness. Kokoda community is famous for its habit to prioritize economic needs rather than education needs. They feel that they need money to live, so working is the most important thing to do to survive. The market is their main house, while the house where they live is only a place to stay at night. Even though their economic esprit is high, their administrative skill is very low. For example, they work hard every day to earn money, but when they get enough money they only used it for fun such as for eating, drinking, party, and so on. They do not really think of their future needs, so their lives always feel deprived.

With this reason and background, one of the community leaders who understood the importance of education for life establishedan institution called as "Emeyodere". Which the name comes from Kokoda language: "Eme" means "come on" and "yodere" means "immediately". So, the name of the foundation is an

27Ibid, p.139. 
invitation to immediately move towards better goals and conditions, while the better goal is started at school as an educational institution that aims to humanize humans.

At first, this foundation only had pesantren. Year to year after it, the foundation developed into madrasah which encouraged students from the Kokoda community to study to achieve the main goal of providing educational services especially for the Kokoda community itself. But, the development of the madrasah is not only because of the Kokoda community. There were many immigrants send their children to study at Emeyodere Educational Institution. Although Emeyodere Foundation has become a madrasah, but the pesantren they have in early period of its establishment to become an educational institution is merged. Therefore, today Emeyodere Foundation consists of Madrasah, that provides formal education, and pesantren.

Beside the support from the community, the attention of the government and the education office is also very important due to the condition of the foundation that is still very apprehensive, the location of the foundation that is far from the city, and the condition of the school that is still far from good. Moreover, the facilities it has are inadequate, the number of teachers is not sufficient to conduct the the teaching process and all of them are temporary employees (honorer), and also the media provided as learning tools to support the learning activities are far from sufficient. Herein lies the concern that must be considered by the government and the local education authorities, even though Emeyodere Foundation is a school which its most of the students are from regional people who must be educated in such a way to become dignified human beings.

It is known Kokoda community are "stubborn". This character is inherited by their young generation. This character has become a problem for the teachers in Emeyodere Foundation to trigger enthusiasm of learning 
for each of their students. The effort to increase this spirit of learning is very difficult to do because the negative trait is truly embedded in them. However, the educators also do not want to lose from that negative thing. The head of Emeyodere Foundation always strives to do things to motivate the students to grow the spirit of learning.

Some motivational efforts have been made by Emeyodere Foundation for the students, including providing assistance or donations in the form of books and other stationery in every semester, distributing school uniforms for underprivileged students, and giving supplementary food in every two weeks. All of those efforts are the ways to motivate the students, but the head of the Foundation and the teachers still feel that they are burdening. The efforts do not just stop, other efforts are always endeavored so that the foundation keeps trying to realize the main goal set as the foundation established. Apart from the efforts mentioned to motivate the students, support from the government, the community and especially from the family are very important. It is because schools and education can develop forward if they get support from various aspects.

\section{Bibliography}

Arsyad, Azhar, Media Pembelajaran. Ed I; Jakarta: Raja Grafindo Persada, 2008.

Damsar, Pengantar Sosiologi Pendidikan. Ed I; Cet. I; Jakarta: Kencana. 2010.

Danim, Sudarwan, Pengantar Kependidikan Landasan, Teori, dan 234 Metafora Pendidikan. Bandung: Alfabeta, 2010.

Hamalik, Oemar,. Psikologi Belajar Mengajar. Cet, VII; Bandung: Sinar Baru Algensindo, 2010, , Proses Belajar Mengajar. Cet. XI; Jakarta: Bumi Aksara, 2010. 
Jhonson, LouAnne, Pengajaran yang Kreatif dan Menarik. Cet. II; t.t: Indeks, 2008.

Nata, Abuddin, Ilmu Pendidikan Isalam. Cet. I; Jakarta: Kencana, 2010.

Rais, Muhammad, "Islam dan Kearifan Lokal; Dialektika Faham dan Praktik Keagamaan Komunitas KokodaPapua dalam Budaya Lokal". Makalah Sekolah Tinggi Agama Islam Negeri (STAIN) Sorong.,2010. Ramayulis, Metodologi Pengajaran Agama Islam. Cet. III; Jakarta: Kalam Mulia, 2001.

Rohman, Arif, Memahami Pendidikan dan Ilmu Pendidikan. Ed I; Cet. II; Yogyakarta: Aswaja Pressindo, 2012.

Sardiman, Interaksi dan Motivasi Belajar Mengajar. Ed I; Jakarta: Rajawali Press, 2008.

Syaodih Sukmadinata, Nana, Metode Penelitian Pendidikan. Cet. IV; Bandung: Rosda, 2008.

Wahyuni, Esa Nur, Motivasi dalam Pembelajaran. Cet. I; Malang: UIN Malang Press, 2009.

Wekke, Ismail Suardi. "Pendidikan Islam dan

Pemberdayaan Masyarakat (Tinjauan Pendidikan Vokasional Pesantren Raudhatul Khuffadz, Sorong)" Hermeneia, Jurnal Kajian Islam Interdisipliner. Yogyakarta: Program Pasca Sarjana UIN Sunan Kalijaga.

., Sari, Yuliana Ratna, Thaqafiyyat,

Jurnal Kajian Budaya Islam. Tifa Syawat dan Entitas Dakwah dalam Budaya Islam: Study Suku Kokoda Sorong Papua Barat, Vol. XIII, Nomor 1, Juni, 2012.

Widodo, Slamet,. Emeyodere dalam Pelayanan Pendidikan Masyarakat Kokoda. Pusat Penelitian dan Pengabdian kepada masyarakat. Sekolah Tinggi Agama Islam Negeri (STAIN) Sorong, 2009

Yudhawati, Ratna., Dkk,. Teori Dasar Psikologi Pendidikan. Cet.I; Jakarta: Prestasi Pustaka, 2011. 